\title{
Korelasi Jenjang Pendidikan Dan Kualifikasi Terhadap Pemahaman Waktu Tanggap Perawat Pada Penanganan Pasien Cedera Kepala DI IGD RSUD ULIN Banjarmasin
}

\author{
M. Sobirin Mohtar \\ Program Studi Sarjana Keperawatan Universitas Sari Mulia \\ Korespondensi: Telepon: 08214882 0454, E-mail: sobirinmuchtar12345@gmail.com
}

DOI: $10.33859 / \mathrm{dksm} . v 1111.547$

\begin{abstract}
Abstrak
Latar Belakang: Cedera kepala merupakan masalah kesehatan yang menyebabkan tingginya angka kecatatan dan kematian dalam pertahunnya. Hal ini sangat penting dilakukan penanganan gawat darurat yang efektif dan efisien. Penanganan tersebut berkaitan dengan pemahaman waktu tanggap perawat, dimana dipengaruhi oleh beberapa faktor salah satunya jenjang pendidikan dan kualifikasi, karena keberhasilan waktu tanggap tergantung pada pemahaman perawat dan kualitas pemberian pertolongan (kualifikasi).

Tujuan: Mengetahui korelasi jenjang pendidikan dan kualifikasi terhadap pemahaman waktu tanggap perawat pada penanganan cedera kepala di IGD RSUD Ulin.

Metode: Penelitian ini menggunakan rancangan kuantitatif dengan pendekatan cross sectional. Populasi dan sampel adalah seluruh perawat pelaksana di IGD RSUD Ulin sebanyak 38 orang dengan teknik total sampling. Instrumen penelitian ini menggunakan kuesioner dengan analisis uji koefisien kontingensi.

Hasil: Jenjang pendidikan terhadap pemahaman waktu tanggap perawat yaitu nilai $\rho=(0.411) \geq \alpha$ $(0.05)$ yang artinya tidak ada korelasi antara keduanya. Sedangkan korelasi kualifikasi terhadap pemahaman waktu tanggap perawat yaitu nilai $\rho=(0.16) \leq \alpha(0.05)$ yang artinya ada korelasi antara keduanya.

Simpulan: Jenjang pendidikan tidak berkorelasi terhadap pemahaman waktu tanggap perawat sedangkan kualifikasi berkorelasi terhadap pemahaman waktu tanggap perawat.

Kata Kunci: Cedera kepala,Jenjang Pendidikan, Kualifikasi, Pemahaman waktu tanggap perawat,.
\end{abstract}




\section{Abstract}

Background: Head injury is a health problem that causes high annual disability and death rates. It is very important to do effective and efficient emergency treatment. Handling is related to understanding response time nurses, which are influenced by several factors one of them level education and qualification because the success of the response time depends on the nurse's understanding and the quality of the assistance (qualification).

Aim: Knowing correlation level education and qualification to understand response time nurses in the management of head injuries in the Emergency Unit of the Ulin District General Hospital.

Method: This research uses a quantitative design with a cross-sectional approach. The population and sample were all nurses in the Emergency Room of the Ulin District General Hospital as many as 38 people with a total sampling technique. This research instrument used a questionnaire with the contingency coefficient test analysis.

Results: Tiereducation to understanding response time nurses namely the value of $\rho=(0.411) \geq \alpha$ (0.05) which means there is none correlation between the two. While correlation qualification to understanding response time nurses namely the value of $\rho=(0.16) \leq \alpha(0.05)$ which means there is a correlation between the two.

Conclusions: Tiereducation does not correlate to understanding response time nurse while qualification correlated to understanding response time nurse.

Keywords: Tier Education, Qualification, Understanding response time nurse, Head injury.

\section{PENDAHULUAN}

Pelayanan gawat darurat adalah pelayanan yang memerlukan penanganan cepat, tepat, dan cermat dalam menentukan prioritas kegawatdaruratan pasien untuk mencegah kecacatan dan kematian (Mahyawati dan Widaryati, 2015). Cedera kepala merupakan salah satu kasus gawat darurat yang terjadi di rumah Sakit. Klasifikasi cedera kepala itu sendiri dibagi menjadi tiga yaitu, cedera kepala ringan, cedera kepala sedang dan cedera kepala berat (Nurarif, 2013).

\section{Menurut World Health Organization} (WHO 2013), menyatakan bahwa kematian cedera kelapa mencatat 2500 kasus kematian yang disebabkan karena kecelakaan lalu lintas. Di Amerika Serikat tahun 2013, kejadian cedera kepala setiap tahun diperkirakan mencapai 500.000, Di Indonesia, cedera kepala berdasarkan hasil Rikesdas 2013 menunjukkan insiden cedera kepala dengan CFR sebanyak 100.000 jiwa meninggal dunia (Depkes RI, 2013).

Di Kalimantan selatan terdapat kasus cedera kepala ringan sebanyak 713, 738 total 
Dinamika Kesehatan Jurnal Kebidanan dan Keperawatan Vol 11 No. 1 Juli 2020 ( ISSN: 2086-3454 EISSN: 2549-4058) url: http://ojs.dinamikakesehatan.unism.ac.id DOI : https://doi.org/10.33859/dksm.v11i1

Korelasi Jenjang Pendidikan Dan Kualifikasi Terhadap Pemahaman Waktu Tanggap Perawat Pada Penanganan Pasien Cedera Kepala DI IGD RSUD ULIN Banjarmasin

keseluruhan 1451 kasus cedera kepala sedang sebanyak 230, 176 total keseluruhan 406 kasus cedera kepala berat sebanyak 186, 182 total keseluruhan 368 kasus. (RSUD Ulin Banjarmasin tahun 2016).

Hasil studi pendahuluan yang di lakukan pada tanggal 10 april 2019 di dapatkan 10 besar kasus kegawatdaruratan 3 bulan terakhir yang terjadi di IGD RSUD Ulin Banjarmasin. cedera kepala menempati nomor urut 3 penyakit terbanyak. Berdasarkan klasifikasi cedera kepala terbanyak di IGD Ulin Banjarmasin adalah CKR sebanyak 102 kasus, dilanjutkan CKS sebanyak 31 kasus, CKB sebanyak 29 kasus.

Waktu tanggap di IGD RSUD Ulin Banjarmasin terhadap penanganan cedera berbeda sesuai dengan kondisi pasien, apabila kondisi pasien termasuk dalam keadaan gawat darurat (Merah) maka waktu tanggap $0-5$ menit, gawat tidak darurat/darurat tidak gawat (kuning) bisa menunggu dengan waktu tunggu 10 menit, tidak gawat dan tidak darurat.

Berdasarkan hal tersebut, maka peneliti bermaksud untuk melakukan penelitian mengenai korelasi Jenjang Pendidikan dan kualifikasi dengan pemahaman waktu tanggap perawat pada penanganan pasien Cedera Kepala di IGD RSUD Ulin Banjarmasin.

\section{METODE}

Penelitian ini menggunakan jenis penelitian kuantitatif dengan rancangan penelitian analitik dengan pendekatan cross sectional. Variabel penelitian ini yaitu variabel dependent dan independent. Populasi dan sampel adalah seluruh perawat pelaksana di IGD RSUD Ulin Banajrmasin sebanyak 38 orang. Sampel diambil dengan teknik total sampling. Sumber data terdiri dari data primer dan sekunder. Instrumen yang digunakan dalam penelitian ini berupa kuesioner. Analisa data yang digunakan dalam penelitian adalah analisis univariat dan bivariat melalui uji koefisien kontingensi. 
Dinamika Kesehatan Jurnal Kebidanan dan Keperawatan Vol 11 No. 1 Juli 2020 ( ISSN: 2086-3454 EISSN: 2549-4058) url: http://ojs.dinamikakesehatan.unism.ac.id DOI : https://doi.org/10.33859/dksm.v11i1

Korelasi Jenjang Pendidikan Dan Kualifikasi Terhadap Pemahaman Waktu Tanggap Perawat Pada Penanganan Pasien Cedera Kepala DI IGD RSUD ULIN Banjarmasin

1. Gambaran Jenjang pendidikan

Gambaran Jenjang pendidikan disajikan pada tabel berikut.

Tabel1 Distribusi Gambaran Jenjang pendidikan

\begin{tabular}{ccc}
\hline Jenjang pendidikan & $(\mathbf{F})$ & $\mathbf{( \% )}$ \\
\hline D3 keperawatan & 29 & 76.3 \\
\hline S1 keperawatan & 5 & 13.2 \\
\hline Profesi Ners & 4 & 10.5 \\
\hline Total & 38 & 100 \\
\hline
\end{tabular}

Berdasarkan tabel 1 Menunjukan bahwa Jenjang pendidikan D3 keperawatan sebanyak 29 responden $(76.3 \%)$, S1 keperawatan sebanyak 5 responden (15.2) dan profesi Ners sebanyak 4 responden (10.5).

2. Gambaran kualifikasi

Gambaran kualifikasi disajikan pada tabel berikut.

Tabel 2 Distribusi Gambaran kualifikasi

\begin{tabular}{ccc}
\hline Kualifikasi & $(\mathbf{F})$ & $\mathbf{( \% )}$ \\
\hline Tidak ada & 5 & 13.2 \\
\hline BTCLS & 33 & 86.8 \\
\hline Total & 38 & 100 \\
\hline
\end{tabular}

Berdasarkan tabel 2 Menunjukan bahwa yang memiliki kualifikasi BTCLS sebanyak 33 responden (86.3\%), Tidak ada mempunyai kualifikasi sebanyak 5 responden (13.2).

3. Gambaran Pemahaman waktu tanggap Perawat

Gambaran Pemahaman waktu tanggap perawat disajikan pada tabel berikut.
Tabel 3 Distribusi Gambaran Pemahaman waktu tanggap perawat

\begin{tabular}{ccc}
\hline $\begin{array}{c}\text { Pemahaman waktu tanggap } \\
\text { perawat }\end{array}$ & (F) & $(\boldsymbol{\%})$ \\
\hline Kurang & 3 & 7.9 \\
\hline Cukup & 9 & 23.7 \\
\hline Baik & 26 & 68.4 \\
\hline Total & 38 & 100.0 \\
\hline
\end{tabular}

Berdasarkan tabel 3 Menunjukan bahwa pemahaman waktu tanggap mengatakan kurang sebanyak 3 responden (7.9\%), cukup sebanyak 9 responden (23.7) dan baik sebanyak 26 responden (68.4).

4. Korelasi Jenjang Pendidikan terhadap pemahaman waktu tanggap Perawat pendidikan perawat terhadap pemahaman waktu tanggap perawat pada penanganan cedera kepala dapat dilihat pada tabel berikut:

Tabel 4 Distribusi pendidikan perawat terhadap pemahaman waktu tanggap perawat pada penanganan cedera kepala di IGD RSUD Ulin Tahun 2019.

\begin{tabular}{|c|c|c|c|c|c|c|c|}
\hline \multirow{3}{*}{$\begin{array}{l}\text { Pendidik } \\
\text { an }\end{array}$} & \multicolumn{5}{|c|}{ Pemahaman } & & \\
\hline & \multicolumn{2}{|c|}{ Kurang } & $\begin{array}{l}\text { Cuku } \\
\text { p }\end{array}$ & \multicolumn{2}{|c|}{ Baik } & \multicolumn{2}{|c|}{ Total } \\
\hline & $\mathrm{F}$ & $\%$ & $\mathrm{~F} \%$ & $\mathrm{~F}$ & $\%$ & $\mathrm{~F}$ & $\%$ \\
\hline $\begin{array}{l}\text { D3 } \\
\text { keperawat } \\
\text { aan }\end{array}$ & 3 & 20 & $\begin{array}{ll}6 & 26 . \\
& 3\end{array}$ & 20 & $\mathrm{~s}$ & 29 & $\begin{array}{l}76 \\
.3\end{array}$ \\
\hline $\begin{array}{l}\text { S1 } \\
\text { Keperawa } \\
\tan \end{array}$ & 1 & 3.1 & 13.1 & 3 & 7 & 5 & $\begin{array}{l}13 \\
.2\end{array}$ \\
\hline $\begin{array}{l}\text { Profesi } \\
\text { Ners }\end{array}$ & 0 & 0 & $0 \quad 0$ & 4 & 10.5 & 4 & 10.5 \\
\hline Total & 4 & 23.1 & $\begin{array}{ll}8 & 29 . \\
& 4\end{array}$ & 26 & 47.5 & $\begin{array}{l}3 \\
8\end{array}$ & 100 \\
\hline
\end{tabular}


Dinamika Kesehatan Jurnal Kebidanan dan Keperawatan Vol 11 No. 1 Juli 2020 ( ISSN: 2086-3454 EISSN: 2549-4058) url: http://ojs.dinamikakesehatan.unism.ac.id DOI : https://doi.org/10.33859/dksm.v11il

Korelasi Jenjang Pendidikan Dan Kualifikasi Terhadap Pemahaman Waktu Tanggap Perawat Pada Penanganan Pasien Cedera Kepala DI IGD RSUD ULIN Banjarmasin

berdasarkan tabel di atas dari 38 respoden

Distribusi Jenjang pendidkan terhadap pemahaman waktu tanggap perawat pada penanganan cedara

kepala

Jenjangpendidikan D3 keperawatan 30 responden (30\%) baik, pada S1 keperawatan dengan 3 responden (7\%) baik dan S1 profesi Ners dengan 4 respoden $(10.5 \%)$ baik.

Hasil dari antara variabel JenjangPendidikan terhadap pemahaman waktu tanggap perawat pada penanganan cedera kepala di IGD RSUD Ulin Banjarmasin ditunjukan pada tabel $4.1 \mathrm{di}$ atas, hasil uji statistik memperlihatkan bahwa nilai $\rho(0,411)>\alpha(0,05)$ artinya $\mathrm{HO}$ tidak diterima karena nilai $\rho$ lebih besar dari $\alpha$. Berdasarkan hasil uji statistik tersebut maka disimpulkan tidak ada Korelasi Jenjang pendidikan terhadap pemahaman waktu tanggap perawat di IGD RSUD Ulin.

\section{Korelasi Kualifikasi terhadap pemahaman} waktu tanggap Perawat

kualifikasi perawat terhadap pemahaman waktu tanggap perawat pada penanganan cedera kepal dapat dilihat pada tabel berikut:

Tabel 5 Korelasi kualifikasi terhadap pemahaman waktu tanggap perawat pada penanganan cedera kepala di IGD RSUD Ulin Banjarmasin.

\begin{tabular}{|c|c|c|c|c|c|c|c|c|}
\hline \multirow{3}{*}{$\begin{array}{l}\text { Kualifik } \\
\text { asi }\end{array}$} & \multicolumn{6}{|c|}{ Pemahaman waktu tanggap } & \multirow{2}{*}{\multicolumn{2}{|c|}{ Total }} \\
\hline & \multicolumn{2}{|c|}{ Kurang } & \multicolumn{2}{|c|}{ Cukup } & \multicolumn{2}{|c|}{ Baik } & & \\
\hline & $\mathrm{F}$ & $\%$ & $\mathrm{~F}$ & $\%$ & $\mathrm{~F}$ & $\%$ & $\mathrm{~F}$ & $\%$ \\
\hline Tidak ada & 2 & 2.7 & 1 & 5.1 & 2 & 5,4 & 5 & 13.2 \\
\hline BTCLS & 1 & 16,5 & 8 & 20,5 & 24 & 50.5 & 33 & 86.8 \\
\hline Total & 3 & 7.9 & 9 & 23,7 & 26 & 68,4 & 38 & 100 \\
\hline$\alpha(0,05)$ & & & & & & & & \\
\hline
\end{tabular}

Berdasarkan tabel diatas, dari 38 responden Distribusi kualifikasi terhadap pemahaman waktu tanggap perawat pada penanganan cedera kepala dengan jumlah responden 2 responden $(5.4 \%$ baik, dan perawat yang memliki kualifikasi BTCLS hanya 24 responden $(50.5 \%)$ baik.

Hasil dari antara variabel kualifikasi terhadap pemahaman waktu tanggap perawat pada penanganan cedera kepala di IGD RSUD Ulin Banjarmasin di tunjukan pada tabel 4.5 diatas, dengan hipotesis HA yaitu ada korelasi antara kualifikasi terhadap pemahaman waktu tanggap perawat pada penanganan cedera kepala di IGD Ulin Banjarmasin. Hasil uji statistik memperlihatkan bahwa nilai $\rho(0.016)<\alpha$ (0.05) artinya Ha diterima karena nilai $\rho$ valuenya lebih kecil dari $\alpha$ berdasarkan hasil uji statistik tersebut maka simpulkan terdapat korelasi kualifikasi terhadap pemahaman waktu tanggap perawat pada 
Dinamika Kesehatan Jurnal Kebidanan dan Keperawatan Vol 11 No. 1 Juli 2020 ( ISSN: 2086-3454 EISSN: 2549-4058) url: http://ojs.dinamikakesehatan.unism.ac.id DOI : https://doi.org/10.33859/dksm.v11i1

Korelasi Jenjang Pendidikan Dan Kualifikasi Terhadap Pemahaman Waktu Tanggap Perawat Pada Penanganan Pasien Cedera Kepala DI IGD RSUD ULIN Banjarmasin

penanganan cedera kepala di IGD RSUD

Ulin Banjarmasin.

\section{PEMBAHASAN}

1. Gambaran Jenjang Pendidikan

Hasil penelitian ini menunjukan bahwa Jenjang pendidikan D3 keperawatan sebanyak 29 responden $(76.3 \%), \quad$ S1 keperawatan sebanyak 5 responden (15.2) dan profesi Ners sebanyak 4 responden (10.5). dari teori nursalam (2011), mengatakan bahwa pendidikan sebagai upaya mengembangkan keunggulan yang tertentu serta menciptakan kreativitas kreativitas cipta karta yang lebih tinggi sednagkan dari teori nurhiyadah (2011), mengatakan bahwa pendidikan keperawatan merupakan suatu proses yang sangat penting yang harus dilalui oleh perawat untuk melangkah yang paling awal dan penting untuk proses profesionalisme keperawatan diindonesia sehingga bisa menata pendidikan keperawatan sebagai pendidikan professional agar perawat memperoleh pendidikan dan pengalaman belajar sesuai degan tuntutan profesi keperawatan.

2. Gambaran kualifikasi

Hasil penelitian ini menunjukan bahwa yang memiliki kualifikasi BTCLS sebanyak 33 responden (86.3\%), Tidak ada mempunyai kualifikasi sebanyak 5 responden (13.2). Teori thoha (2011) menyebutkan bahwa suatu pelatihan dengan kegiatan yang dikuti akan memperbaiki kemampuan tenaga kerja kesehatan dan mampu untuk melaksanakan pelayanan kesehatan serta berorientasi pada kegiatan secara langsung. Sedangkan dari teori Sastrohadiwiryo (2012), menyebutkan semakin tinggi kuantitas tenaga kerja, maka problem yang dihadapi semakin komplek sehingga diberikan pelatihan pada para tenaga kerja untuk memperoleh nilai tambah tenaga kerja. Maka pelayanan yang diberikan akan meningkat dan berkembangkan dari pemahaman, sikap dan keterampilan tenaga kerja.

3. Gambaran Pemahaman waktu tanggap Perawat

Hasil penelitian ini menunjukan bahwa penegetahuan waktu tanggap mengatakan Kurang sebanyak 3 responden (7.9\%), cukup sebanyak 9 responden (23.7) dan Baik sebanyak 26 responden (68.4). Berdasarkan teori widiasih (2008), menyebutkan dalam memberikan bantuan gawat darurat petugas harus memiliki 3 unsur kesiapan seperti kesiapan pemahaman dan keterampilan dikarenakan akan berkaitan dengan upaya penyelamatan langsung terhadap pasien. Sejalan dari teori wahjono (2010) mengatakan setiap orang harus mempunyai kekuatan dan kelemahan yang dimana harus memiliki kemampuan yang membuat lebih unggul dibandingkan 
Dinamika Kesehatan Jurnal Kebidanan dan Keperawatan Vol 11 No. 1 Juli 2020 ( ISSN: 2086-3454 EISSN: 2549-4058) url: http://ojs.dinamikakesehatan.unism.ac.id DOI : https://doi.org/10.33859/dksm.v11i1

Korelasi Jenjang Pendidikan Dan Kualifikasi Terhadap Pemahaman Waktu Tanggap Perawat Pada Penanganan Pasien Cedera Kepala DI IGD RSUD ULIN Banjarmasin

dari orang lain seperti pemahaman (Knowledge).

4. Korelasi Jenjang Pendidikan terhadap pemahaman waktu tanggap Perawat

Dari hasil kuesioner yang dibagikan oleh peneliti kepada perawat pelaksana di IGD menunjukan bahwa Jenjang pendidikan terhadap pemahaman waktu tanggap perawat di IGD yaitu dari D3 keperawatan sebanyak 20 responden $(30 \%), \quad$ S1 keperawatn sebanyak $3(7 \%)$, S1 profesi Ners sebanyak 4 (10.5\%).

Hasil yang didapatkan variabel Jenjang Pendidikan terhadap pemahaman waktu tanggap perawat pada penanganan cedera kepala di IGD RSUD Ulin Banjarmasin ditunjukan pada tabel 4.4 di atas, hasil uji statistik memperlihatkan bahwa nilai $\rho$ $(0,411)>\alpha(0,05)$ artinya $\mathrm{HO}$ tidak diterima karena nilai $\rho$ lebih besar dari $\alpha$. Berdasarkan hasil uji statistik tersebut maka disimpulkan tidak ada Korelasi Jenjang pendidikan terhadap pemahaman waktu tanggap perawat di IGD RSUD Ulin Banjarmasin. Hasil ini Sejalan dari penelitian Vitrise Maatilu, dkk (2014), faktor-faktor yang berhubungan terhadap waktu tanggap perawat pada penanganan pasien gawat darurat di IGD RSUP Prof.dr.R.D. Kandau manado yang menyebutkan bahwa tidak adaanya korelasi antara pendidikan perawat terhadap waktu tanggap perawat pada penangana pasien gawat darurat.

Sedangkan untuk Jenjang pendidikan DIII keperawatan sebanyak 20 (30\%), baik. Keadaan tersebut menurut didukung oleh penelitian sitorus (2011). Meskipun lulusan program Diploma III disebut juga sebagai perawat professional pemula harus sudah memilki sikap professional yang dilihat dari keterampian teknis, intelektual dan keperawatan professional berdasarkan asuhan keperawatn dan etik keperawatan namun pendidikan keperawatan yang harus ditingkatkan pendidikan keperawatan yang dimana sikap, penegtahuan dan keterampilan profesional biasa berkembangkan semaksimal mungkin sesuai peran dan fungsinya sebagai perawat professional.

Dari data diatas menyebutkan Jenjang pendidkkan S1 keperawatan sebanyak 3 responden (7\%) dan S1 Profesi ners sebanyak (10.5\%). hal tersebut sejalan dengan penelitian yang telah dilakukan oleh Kuncoroningrat \& pariani (2012), menyebutkan makin tinggi pendidikan seseorang maka akan mudah menerima informasi sehingga pemahaman yang didapat banyak, sebaliknya pendidikan yang kurang akan menghambat perkembangan sikap seseorang nilai -nilai yang diperkenalkan. Maka dengan itu seseorang yang berpendidikan yang tinggi 
Dinamika Kesehatan Jurnal Kebidanan dan Keperawatan Vol 11 No. 1 Juli 2020 ( ISSN: 2086-3454 EISSN: 2549-4058) url: http://ojs.dinamikakesehatan.unism.ac.id DOI : https://doi.org/10.33859/dksm.v11i1

Korelasi Jenjang Pendidikan Dan Kualifikasi Terhadap Pemahaman Waktu Tanggap Perawat Pada Penanganan Pasien Cedera Kepala DI IGD RSUD ULIN Banjarmasin

tidak mempengaruhi pemahaman sesorang meskipun Jenjang pendidikan lebih tinggi.

Maka dengan hal ini banyak faktor - faktor lain menghambat penelitian ini maka didukung dari penelitian Wa Ode Nur Isnah Sabriyati (2012). Faktor -faktor yang berhubungan ketepana waktu tanggap penanganan kasus pada waktu tanggap perawat di instalasi gawat darurat bedah dan non-bedah rsup dr. wahidin sudirohusodo menyebutkan faktor menghambat perawat untuk melakukan pelayanan kepada pasien yaitu ketersediaan stretcher serta petugas tiase.

5. Korelasi kualifikasi terhadap pemahaman waktu tanggap Perawat

Dari 38 orang Distribusi kualifikasi terhadap pemahaman waktu tanggap perawat pada penanganan cedera kepala dengan jumlah responden 38 (100), sedangkan yang tidak memiliki setifikasi hanya 5 responden (13.2) dan perawat yang memliki kualifikasi BTCLS hanya 33 responden (86.8).

Hasil dari data diatas menyebutkan antara variabel kualifikasi terhadap pemahaman waktu tanggap perawat pada penanganan cedera kepala di IGD RSUD Ulin di tunjukan pada tabel 4.5 diatas, dengan hipotesis HA yaitu ada korelasi antara kualifikasi terhadap pemahaman waktu tanggap perawat pada penanganan cedera kepala di IGD Ulin . Hasil uji statistik memperlihatkan bahwa nilai $\rho(0.016)<\alpha$ (0.05) artinya Ha diterima karena nilai $\rho$ lebih kecil dari $\alpha$ berdasarkan hasil uji statistik tersebut maka simpulkan terdapat korelasi kualifikasi terhadap pemahaman waktu tanggap perawat pada penanganan cedera kepala di IGD RSUD Ulin .

Penelitian ini sejalan dengan teori yang menjelaskan bahwa pelatiahan memberikan dampak yang besar terhadap kemampuan seseorang dalam mengambi keputusan dengan situasi kritis seperti pada penanganan kasus cedera kepala ynga dimana peserta harus memilki teori dan juga dalam aplikasi yang dimana memudahkan dalam memberikan pelayanan diunit rawat darurat dalam apapun terhadap pasien dengan kasus yang bebeda - beda dalam setiap satu waktu (yayasan Ambulans gawat Darurat, 2014).

Hasil penelitian ini selarawas dengan penelitian Awases (2012) menyebutkan pelatihan kewadaruratan memiliki korelasi dengan waktun tanggap perawat di IGD pada kasus cedera kepala di IGD. Hasil pada penelitian ini didukung dari penelitian Lontoh (2013) tentang pengaruh pelatihan dengan teori bantuan hidup dasar kepada perawat sehingga pemahaman waktu tanggap perawat pada pasien cedera menyatkan bahwa adanya korelasi antara pelatihan dengan pemahaman perawat. 
Menurut Sastrohadiwiryo (2012) semakin tinggi kuantitas tenaga kerja, maka problem yang timbul akan semakin kompleks, salah satu jalan yang harus di tempuh adalah memberikan pelatihan kepada para tenaga kerja ini juga dimaksudkan untuk memperoleh nilai tambah tambah tenaga kerja yang berangkutan, terutama yang berhubungan dengan meningkatnya dan berkembangnya pemahaman, sikap, dan keterampilan tenaga kerja.

\section{SIMPULAN}

Peneliti menyimpulkan bahwa kualifikasi berkorelasi terhadap pemahaman waktu tanggap perawat pada penanganan cedera kepala. sedangkan Jenjang pendidikan tidak berkorelasi terhadap pemahaman waktu tanggap perawat pada penanganan cedera kepala. Kepada peneliti selanjutnya harapannya bisa melakukan penelitian dengan variabel yang lain atau menambahkan variabel yang ada seperti faktor yang mempengaruhi waktu tanggap yaitu lama kerja, beban kerja, umur, motivasi dan ketersediaan alat.

\section{DAFTAR PUSTAKA}

Kusuma dan Nurarif. 2015. APLIKASI Asuhan Keperawatan Berdasarkan Diagnosa medis \& NANDA NIC-NOC. Jogjakarta: Medi Action.

Maatilu. 2014. Faktor-Faktor Yang Berhubungan Dengan Response Time Perawat Pada Penanganan Pasien Gawat Darurat Di IGD RSUD. Prof. Dr. R.D. Kondou Manado. Universitas Sam Ratulangi: Manado.

Mahyawati dan Widaryati. (2015). Hubungaan Kegawatdaruratan Pasien Dengan Waktu Tanggap Perawat di IGD RS PKU Muhammadiyah Yogyakarta Skripsi, Program Studi Ners, STIKES Aisyiah Yogyakarta.

Nurhidayah. 2011. Konsep Pendidikan Keperawatan. Jakarta : Salemba Medika.

Nursalam. 2011. Konsep Penerapan Metode Penelitian Ilmu Keperawatan. Jakarta: Salemba.

Sastrohadiwiryo. S., B. 2012. Manajemen Tenaga Kerja Indonesia: Pendekatan Administrasi Dan Operasional. Jakarta; Buki Aksara.

Sitorus. 2011. Manajemen Keperawatan; Manajemen Keperawatan Di Ruang Rawat, ed 1. Jakarta: Cv Sagung Seto.

Thoha. 2011. Konsep Pelayanan Kesehatan. Jakarta: Cipta Raksara. 
Wa Ode, dkk. 2012. Faktor-Faktor Yang Berhubungan Dengan Ketepatan Waktu Tanggap Penanganan Kasus Pada Response Time I Di Instalasi Gawat Darurat Bedah Dan NonBedah RSUP Dr. Wahidin Sudirohusodo. Mahasiswa Emergency And Disaster Management, Biomedik, Program Pasca Sarjana, Universitas Hasanuddin.

Wahjono. 2010. Pengetahuan Pelayanan Kesehatan. Jakarta: Salemba Medika.

WHO. 2013. The Incidence of Head Injury. World Health Organization Emergency.

Widiasih. 2010. Faktor Yang Berhubungan Dengan Respon Time. Yogyakarta: Publishing 